\title{
Dispersion of surface waves along various paths to Uppsala, Sweden
}

\author{
Tersuo A. SANTo \\ Ricevuto il 27 settembre 1962 \\ $P$ P R T I I \\ AROTIO AND ATLANTIO OCEANS
}

\section{I.TRODUCTION.}

In continuation of Part I (Santo 1962), group) velocity dispersion of surface waves along varions oceanice paths to Uppsala, Sweden, will be reported in this paper. Materials and the method used are quite similar to the previous ones, i. e. group velocities of Love and Rayleigh waves were obtained from records by ultra-long-period Press-Ewing seismographs for the shocks with numbers $00-60$ and $61-90$, and for the other shocks from the records by long-period Benioft seismographs at the Seismological Institute, Uppsala, Sweden. In order to give characteristic numbers to the dispersion data along every oceanic path, they are compared with the elassified curves which the writel has obtained previously (see Fig. 1 of Part I) along other oceanic paths. Love wave dispersion eures are denoted by Roman numerals and Rayleigh wave curves by Arabic numerals.

\section{DISPERSION OF STRFACE WAVES IN THE ARCTIC OCEAN.}

Travelling paths are shown in Fig. 1 in which solid lines with double circle epicenters and clashed lines with filled circle epicenter's respectively mean those along which both Love and Rayleigh waves and only Rayleigh waves are well developed. Data about the shocks are presented in Table I after the Preliminary Reports of U.S.C.G.S. Diagrams a) and b) in Fig. 1 show some examples of Rayleigh wave dispersion along 
Table 1 - List of sulocks ron ARCtic regiox

$h$ - focal depth, $\quad I=$ magnitude. $\quad I-$ distance

\begin{tabular}{|c|c|c|c|c|c|c|c|c|c|}
\hline No. & listrict & & 1)ate & & $\begin{array}{c}\text { Origin Time } \\
\text { (G.M.T.) }\end{array}$ & Epicenter & $\underset{k}{h}$ & $M I$ & $\underset{\mathrm{k} m}{D}$ \\
\hline 06 & Off coast of Oregon & June & 23 & 1961 & $08{ }^{\prime \prime} 55^{\mathrm{m}} 55.2 \mathrm{~s}$ & $43.9^{\circ} \mathrm{N} \quad 128.9^{\circ} \mathrm{W}$ & 56 & - & 8100 \\
\hline 44 & Vancouver Island region & Oet. & 29 & 1961 & $09 \quad 12 \quad 15.7$ & $49.0 \mathrm{~N} 128.7 \mathrm{~W}$ & 16 & - & 7570 \\
\hline 22 & Queen Charlotte Islands & Sept. & 08 & 1961 & $0452 \quad 10.3$ & $51.8 \mathrm{~N} 131.2 \mathrm{~W}$ & 54 & - & 7320 \\
\hline 122 & Queen Charlotte Islands & July & 04 & 1960 & $0428 \quad 33$ & $52 \quad \mathrm{~N} 131.5 \mathrm{WT}$ & $\ldots-$ & $6 . \overline{5}$ & 7300 \\
\hline 23 & Kenai Peninsula. . & Sept. & 05 & 1961 & 113437.3 & $59.8 \mathrm{~N} \quad \mathbf{5 0} 0.6 \mathrm{~W}$ & $4+$ & 6 & 6700 \\
\hline 94 & Kodiak I., Alaska region & l)ec. & 09 & 1961 & $02 \quad 15 \quad 22.0$ & $56.3 \mathrm{~N} \quad \mathrm{I} 53.9 \mathrm{~W}$ & 31 & 5.5 & 7100 \\
\hline $1+3$ & Alaska Peninsula . . . & May & 13 & 1960 & $1607 \quad 12$ & $55 \quad \mathrm{~N} 161.5 \mathrm{~W}$ & - & - & 7250 \\
\hline 27 & Fox Islands, Aleutian Is. . & Aug. & 29 & 1961 & $1+51 \quad 1+.2$ & $52.2 \times 170.8 \mathrm{~W}$ & +1 & 5 & 7560 \\
\hline 37 & Fox Islands, Aleutian Is. . & Aug. & 08 & 1961 & $1218 \quad 18.9$ & $50.9 \mathrm{~N} \quad 170.7 \mathrm{~W}$ & 24 & 6 & 7725 \\
\hline 126 & Fox Islands, Aleutian Is. . & Sept. & 02 & 1960 & $2202 \quad 48.9$ & $52.0 \mathrm{~N} 171.4 \mathrm{~W}$ & 49 & 6 & 7600 \\
\hline 01 & Severnaya Zemlya regrion. . & June & 29 & 1961 & 220121.0 & $85.0 \mathrm{~N} \quad 97.3 \mathrm{~F}$ & 11 & - & 3300 \\
\hline 121 & Andreanof Is., Alentian Is. . & July & 03 & 1960 & $2020 \quad 46$ & $50.5 \mathrm{~N} 177 \quad \mathrm{~W}$ & - & 6.5 & 7700 \\
\hline 24 & Andreanof Is., Aleutian Is. . & Sept. & 04 & 1961 & $09 \quad 49 \quad 10.7$ & $51.4 N 178.1 \mathrm{~W}$ & 35 & 6 & 7575 \\
\hline 20 & Andreanof Is., Aleutian Is. . & Sept. & 11 & 1961 & $0246 \quad 43.3$ & $51.3 \mathrm{~N} \quad 179.7 \mathrm{~W}$ & 15 & - & 7560 \\
\hline 113 & Rat Islands, Alentian Is. . & Aug. & 04 & 1960 & 073453.8 & $51.4 \mathrm{~N} 179.1 \mathrm{E}$ & 83 & - & 7550 \\
\hline 90 & Rat Islands, Aleutian Is. . & Iec. & 30 & 1961 & $00 \quad 39 \quad 24.0$ & $52.3 \mathrm{~N} 177.7 \mathrm{E}$ & 52 & $\tau$ & 7430 \\
\hline 02 & Near Is., Aleutian Is. . . . & June & 26 & 1961 & $1+4726.1$ & $52 .+\mathrm{N} 174.5 \mathrm{E}$ & 60 & - & 7400 \\
\hline 68 & Near Islands, Alentian Is. . . . & May. & 17 & 1961 & $1929 \quad 19.3$ & $52.0 \mathrm{~N} / 73.9 \mathrm{E}$ & 21 & 6.5 & 7420 \\
\hline
\end{tabular}




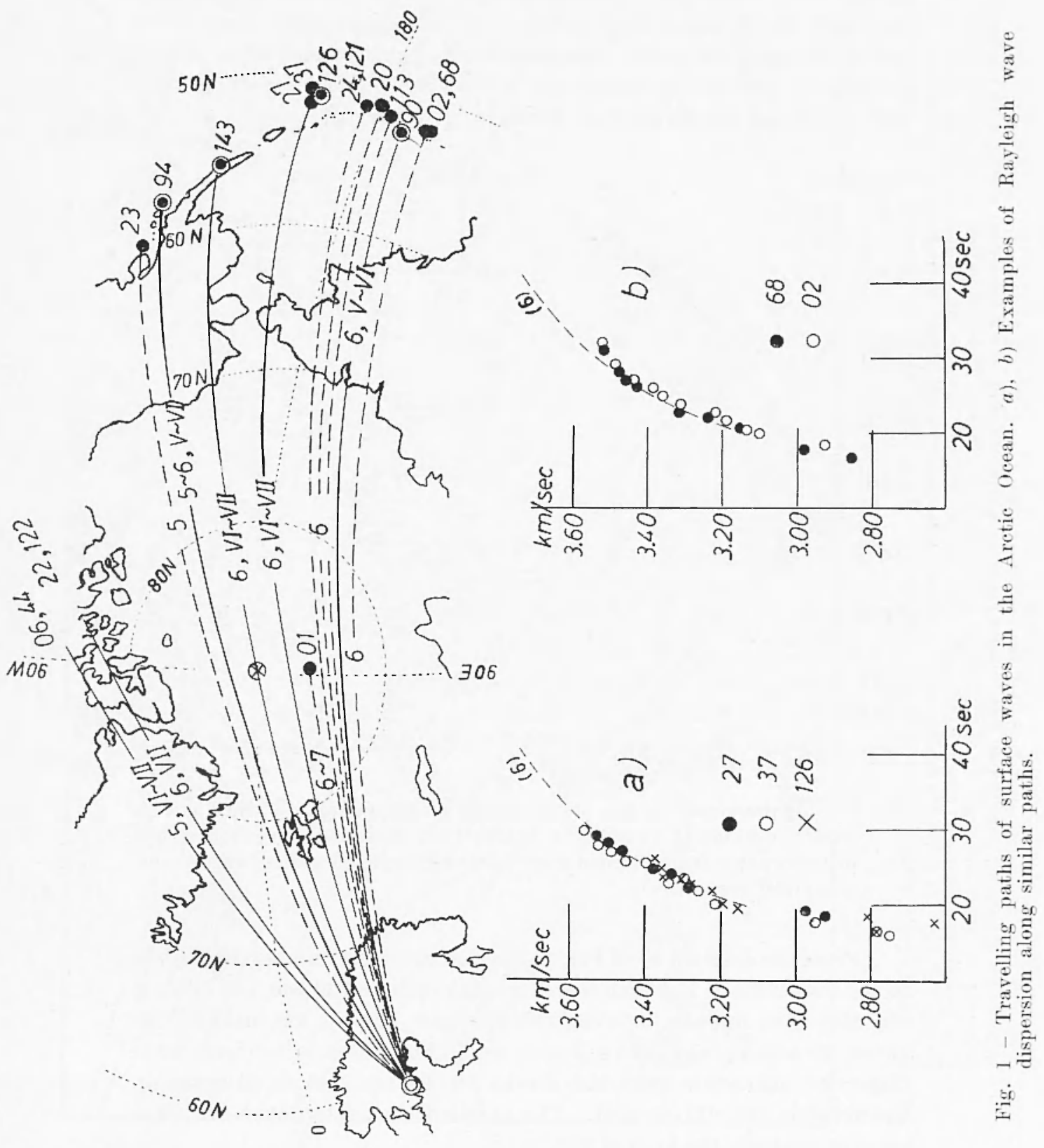


approximately the same paths. Is expected, these data lie exactly on the same curve. The classified dispersion curve (6) is given for comparison. Thus, we assign a characteristic number $(6)$ to the dispersion of Rayleigh waves along these paths. The dispersion data along other paths, arranged clockwise, are given in diagrams $a$ ) and $b$ ) in Fig. 2. In order to prevent the complexity of the figures, some of the dispersion data which an be represented by others, were omitted.
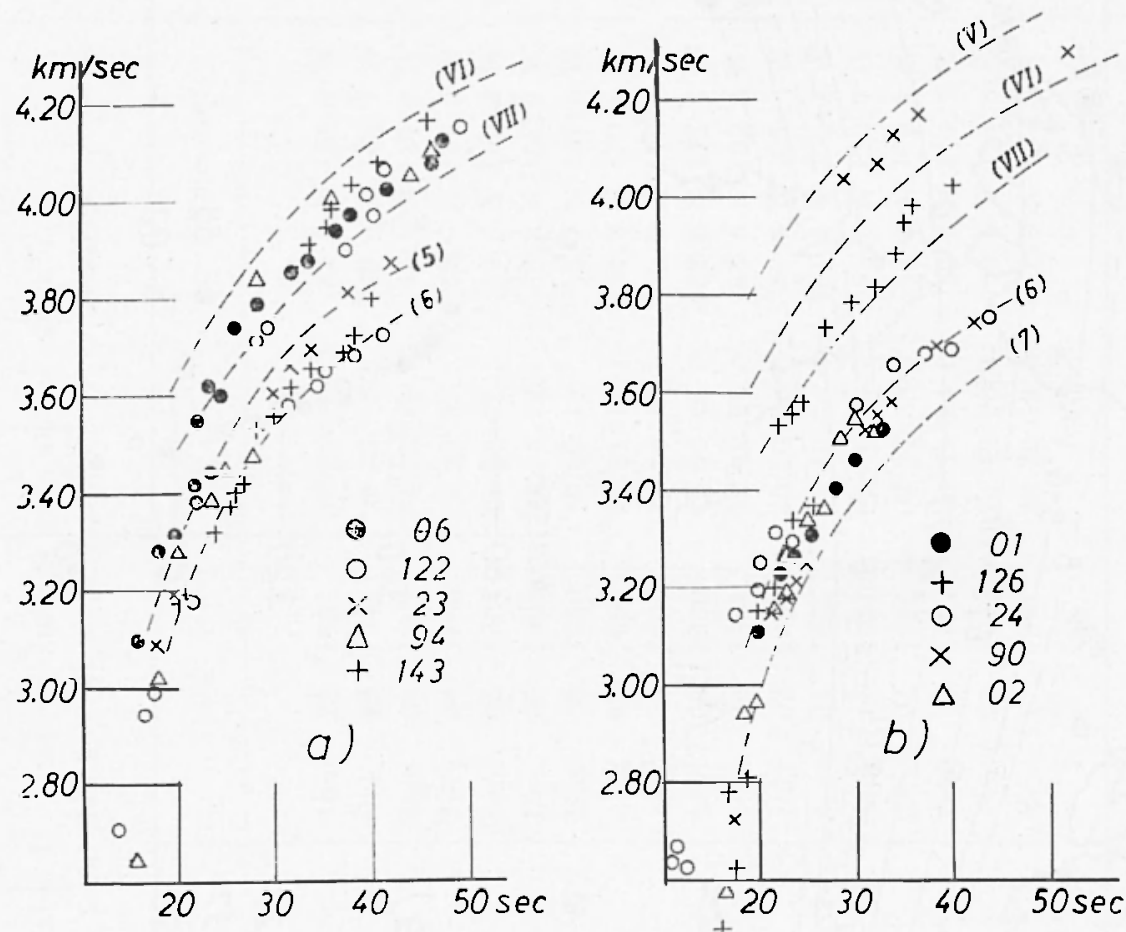

Fig. 2 - Dispersion of surface waves in the Arctic Ocean. Dashed curves with two kinds of numbers in loakets are classified dispersion curves of Love waves (with Roman numerals) and Rayleigh waves (with Arabie numerals) respectively.

From the diagram $a$ ) of Fig. 2, the characteristic number (6) is given to the dispersion of Rayleigh waves from the shocks 122 and 143 . When the dispersion data lie between two reference curves, for instance between (5) and (6), a notation (5-6) is used. For instance, for Love wave dispersion characters from the shocks 06,94 and 143 in diagram $a$ ), the notation (VI-VII) is used. The numbers thus determined are given on every path in the map of Fig. 1. 


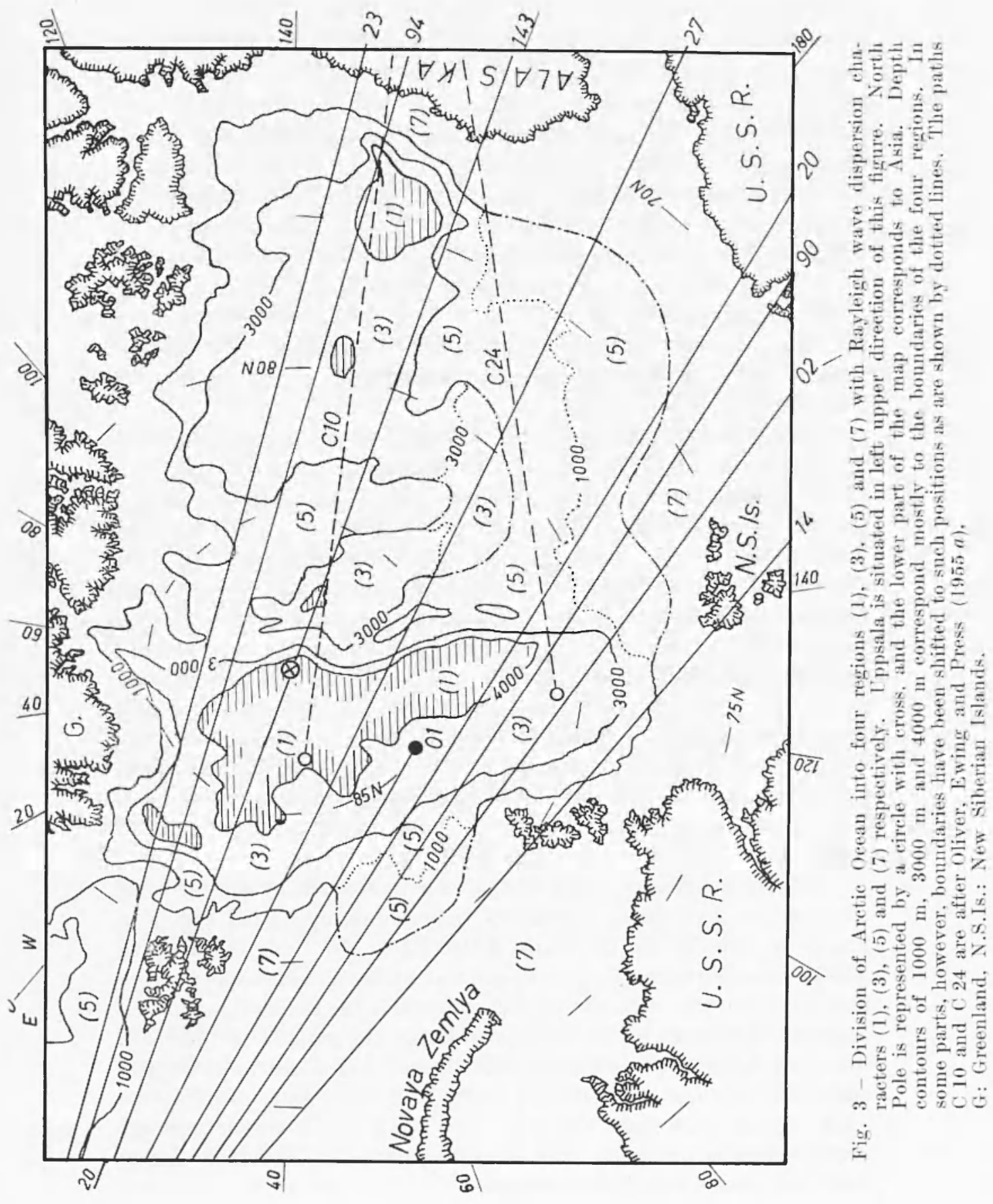


Previously, the author divided the southwestern Pacific area into four regions (1), (3), (5) and (7) with Rayleigh wave dispersion characters (1), (3), (5) and (7) respectively (Santio 1961). The same method was applied to the Arctic Ocean area.

At first, the depth contours of $1000 \mathrm{~m}, 3000 \mathrm{~m}$ and $4000 \mathrm{~m}$ in Fig. 3, modified from the Time Atlas (London Press 1959), were supposed to be the boundaries of the four regions (7), (5), (3) and (1) respectively. As group velocities of Rayleigl waves with the dispersion characters (7), (5), (3) and (1) are known for each period, the travel times of Rayleigh waves along each path, and accordingly the resulting group velocities $V$ (calc.) were found for each period. These values were compared to the observed velocities $V$ (obs.). After that, the preliminary boundary lines were moved so as to make $V$ (calc.) agree as nearly as possible with $\mathrm{V}$ (obs.).

This procedure was performed for eight representative paths from $23,94,143,01,27,20,90$ and 02 . The remaining part of the first five (outside the map in Fig. 3), which passes over continent or sea regions shallower than $1000 \mathrm{~m}$, is considered to be region (7). The remaining part for the other three paths from 20,90 and 02 passes over rather deep sea region in the western part of the Bering Sea. Therefore, the same suppositions as for the Arctic Ocean are male for these parts. The values of $V$ (calc.) are quite the same as $V$ (obs.) along the four northern paths from $23,94,143$ and 01 without any corrections of the preliminary boundaries, but they are smaller than the latter along the other four paths from 27, 20,90 and 02 . In order to approach $V$ (calc.) to $V$ (obs.) along these four paths, path lengths over any region with low group velocities must be decreased. Is these paths occupy a region with more than $3000 \mathrm{~m}$ depth in the western part of the Bering Sea, such corrections have to be male in the Arctic Ocean area.

Suitable boundaries were found, after several trials, by shifting some parts of the preliminary boundaries (represented by dotted curves in Fig. 3) to those shown by dashed-dotted lines. In Table II, the path lengths of each region $\left(D_{1}, D_{3}, D_{5}\right.$ and $\left.D_{5}\right)$ finally obtained along every path are given, with values in bracket referring to the Bering Sea. V(calc.) as obtained from the final division map along nine paths in all (one path from 14 treated as a continental path in Part $I$ is added for reference) are given for three different periods in Table III. As is seen in this Table, $V$ (calc.) are quite the same as $V$ (obs.), which means that our division map is quite suitable for satisfying all the dispersion data of Rayleigh waves in the Aretic Ocean. 
Oliver, Ewing and Press (1955 a) observed Rayleigh wave dispersion along three paths in the Arctic. Excluding their path $\mathrm{C}$ it because of limitation to too small period range, the other data along two paths C10 and C24 are used also in the present work. The paths are shown in Fig. 3 by dashed lines and $D i$ and $V$ (calc.) or $V$ (obs.) for these paths are added in Tables II and III. The present division is found to be quite satisfactory also for these data. Oborina's (1961) results also agree.

T'able II - Travelding patil lexgths (IN $\mathrm{km}$ ) for each region along EVERY PATII.

\begin{tabular}{|c|c|c|c|c|c|}
\hline No. & $D_{1}$ & $D_{3}$ & $D_{5}$ & $D_{\tau}$ & $D$ \\
\hline 23 & 90 & 1990 & 2100 & 2520 & 6700 \\
\hline 94 & 290 & 1530 & 1750 & 3530 & 7100 \\
\hline 143 & 740 & 1420 & 230 & 4860 & 7250 \\
\hline 27 & 490 & 980 & 1150 & 4940 & 7560 \\
\hline 01 & 0 & 380 & 250 & 2670 & 3300 \\
\hline 20 & 260 & $\begin{array}{l}1270 \\
(660)\end{array}$ & $\begin{array}{l}1850 \\
(390)\end{array}$ & 4180 & 7560 \\
\hline 90 & 0 & $\begin{array}{l}1520 \\
(840)\end{array}$ & $\begin{array}{l}1260 \\
(200)\end{array}$ & 4650 & 7430 \\
\hline 02 & $\begin{array}{c}150 \\
(150)\end{array}$ & $\begin{array}{l}1290 \\
(680)\end{array}$ & $\begin{array}{r}1050 \\
(50)\end{array}$ & 4910 & 7400 \\
\hline 14 & 0 & 0 & 370 & 6470 & 6840 \\
\hline $\mathrm{C} 24$ & 0 & 260 & 1280 & 1430 & 2970 \\
\hline $\mathrm{ClO}$ & 640 & 1070 & 540 & 1050 & 3300 \\
\hline
\end{tabular}

Furthermore, the same authors studied the appearance of $\mathrm{Lg}$ along many paths crossing the Arctic Ocean. Their observations are also satisfactorily explained if we consider the regions (1) and (3) to prevent the propagation of $\mathrm{Lg}$.

Another point must be added here concerning the relation between the depth of the sea and the dispersion character of Rayleigh waves. 


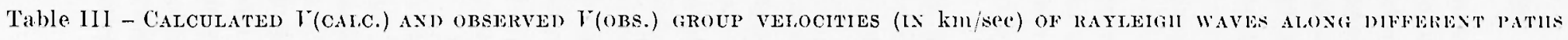
FOR THREE DIFFERENT PERIONS.

$t_{i}$ - travel time within each region, $i=1,3,5,7$.

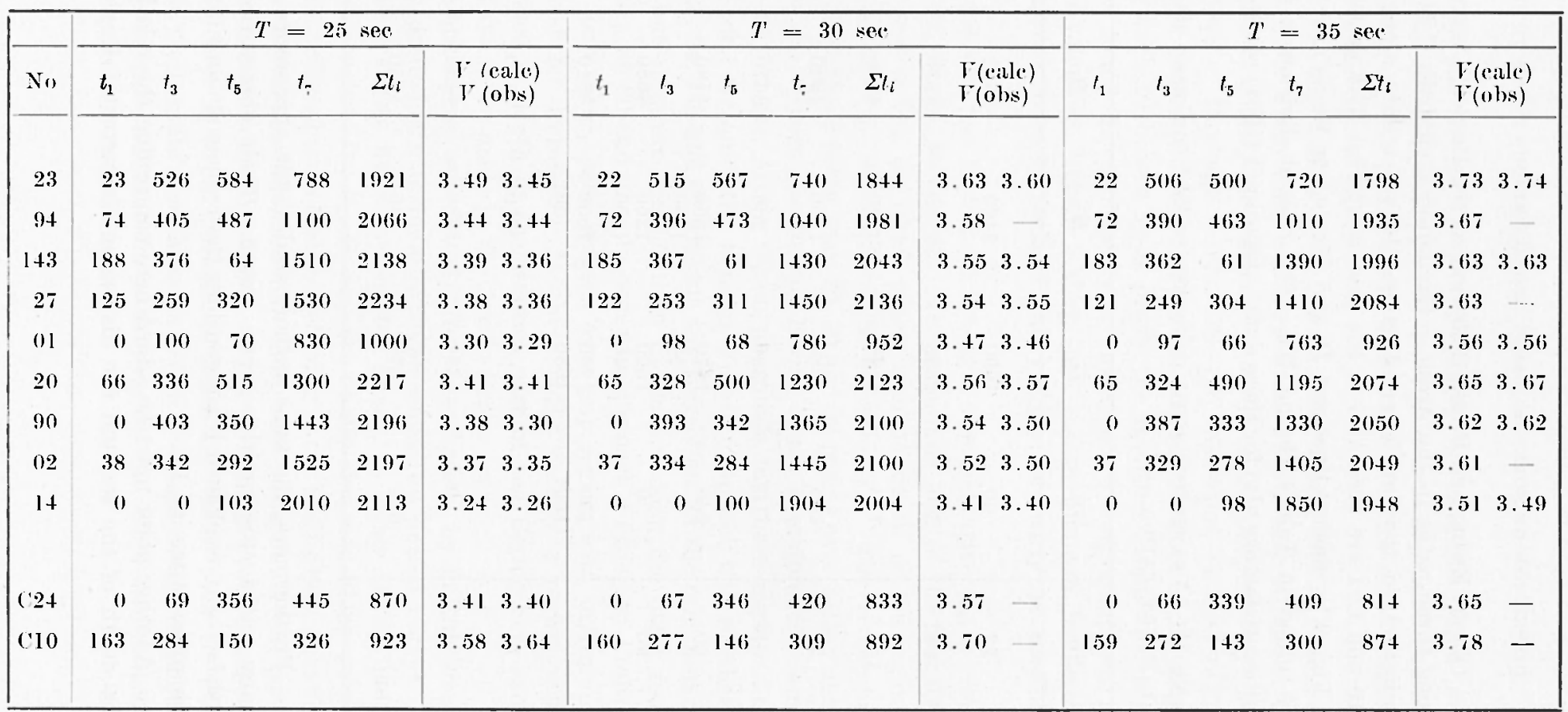


In previous investigations (Santo 1961), the writer found that on the western side of the Andesite line, Rayleigh waves still exhibit a dispersion character of (3) even in a sea region deeper than $4000 \mathrm{~m}$. This was considered characteristic for the crustal condition on the western side of the Andesite line. On the eastern side of that line, Rayleigh waves show "purely oceanic dispersion character" of (1) in sea regions deeper than $4000 \mathrm{~m}$. Our present division map of the Arctic Ocean tells us that Rayleigh waves have a purely oceanic character (1) only in regions of more than $4000 \mathrm{~m}$ depth. Though the writer has not finished his studies of the relation between the depth of the sea and the dispersion character of Rayleigh waves in the whole vast area east of the Andesite line, i. e. in the ordinary Pacific Ocean area, the Arctic Ocean seems to have the same relation between sea depth and crustal condition as the Pacific Ocean excluding its south-western part. This suggestion agrees with the section of the crust across the region (1) as given by Hope (1958) according to Demençkaya.

It must also be noticed from the division map that there are a few exceptional regions in which the crustal condition may be a little more oceanic than to be expected from the sea depth. These regions are limited by dotted and dashed-dotted curves in the map. For instance, the region from New Siberian Islands (N.S. Is.) towards southeast has the characteristic number (5) instead of (7), which is expected from the sea depth, shallower than $1000 \mathrm{~m}$.

The bathymetric map in Fig. 3 was modified from the Time Atlas (London Press 1959). There is another much more detailed map, given by Heezen and Ewing (1961), based upon Soviet data. Comparing these two maps, there are some slight differences. But it was found that these differences were so small as to be of no consequence for our conclusions.

DISPERSION OF SURFACE WAVES IN THE ATIANTIC OCEAN.

Travelling paths of surface waves and data of shocks are given in the map of Fig. 4 and in Table IV respectively.

In interesting fact can be recognized in the Rayleigh wave dispersion in diagram $b$ ) of Fig. 4 for several Chile shocks. That is, the group velocities in longer period range are somewhat depressed compared to the classified curves (5) and (6). In Part I the same feature was recognized along paths through the southern part of the Mid-Atlantic 


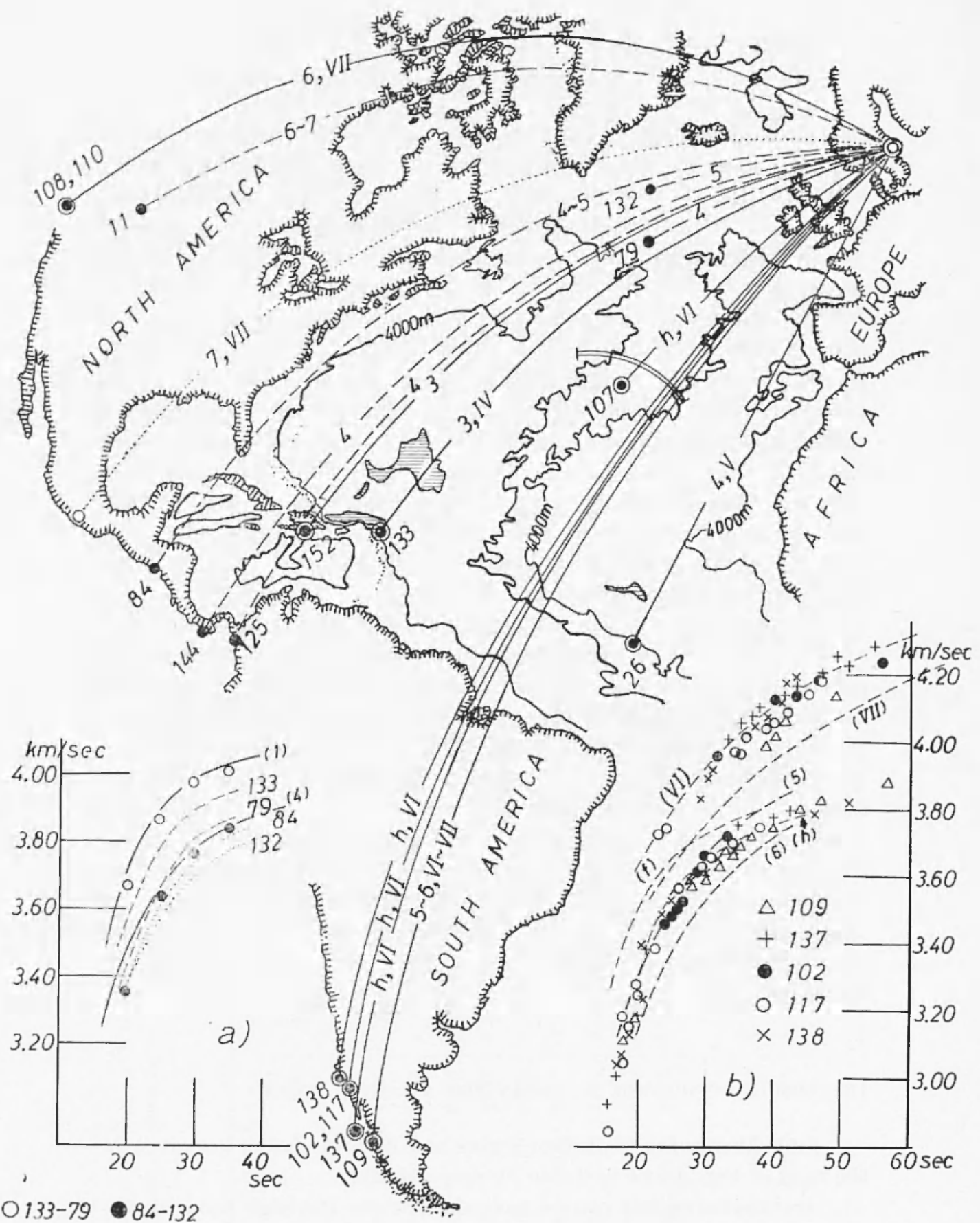

Fig. 4 - Travelling paths of surface waves in the Atlantic Ocean. Depth contour in tho ocean corresponds to a depth of $4000 \mathrm{~m}$, and the hatched region indicates depths exceeding $6000 \mathrm{~m}$. Double arc line north of epicenter 107 is the refraction profile by Ewing and Ewing (1959). A dotted line over the North American continent is the path along which surface wave dispersion was observed by Bath (1959). $(8+-132)$.

a) Calculated group velocities of Rayleigh waves hetween two epicenters (133-79),

b) Dispersion from (hile shocks. A reference curve $(h)$ means the smoothed dispersion curve from 107 to Lppsala (see Figr. 5-a). 


\begin{tabular}{|c|c|c|c|c|c|c|c|c|c|c|c|c|c|c|c|c|c|}
\hline$\theta \Xi$ & $\begin{array}{l}10 \\
\stackrel{1}{1} \\
\text { N }\end{array}$ & $\frac{8}{\infty}$ & $\begin{array}{l}\stackrel{0}{0} \\
0 \\
+ \\
+1\end{array}$ & $\begin{array}{l}\stackrel{0}{0} \\
\stackrel{9}{N} \\
i\end{array}$ & $\begin{array}{l}0 \\
0 \\
0 \\
0\end{array}$ & $\begin{array}{l}0 \\
+ \\
\infty \\
0\end{array}$ & $\underset{0}{0}$ & $\frac{8}{\infty}$ & $\begin{array}{l}\stackrel{0}{0} \\
i \\
1\end{array}$ & 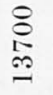 & 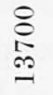 & $\begin{array}{l}0 \\
10 \\
\infty \\
9 \\
-1\end{array}$ & $\begin{array}{l}\stackrel{0}{10} \\
\stackrel{5}{+} \\
\stackrel{-1}{-}\end{array}$ & \begin{tabular}{l}
$\infty$ \\
$\infty$ \\
$\stackrel{N}{+}$ \\
\multirow{-}{+}{}
\end{tabular} & \begin{tabular}{l}
10 \\
\multirow{\infty}{*}{} \\
$\infty$ \\
$\infty$
\end{tabular} & $\begin{array}{l}\infty \\
+ \\
+\infty\end{array}$ & $\begin{array}{l}0 \\
10 \\
6 \\
1\end{array}$ \\
\hline$\vec{z}$ & & 10 & & & 0 & 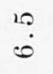 & 0 & 18 & 0 & 1 & N & 1 & $\stackrel{10}{0}$ & N & $\begin{array}{l}10 \\
10\end{array}$ & & \\
\hline$\approx \equiv$ & $\dddot{0}$ & $\stackrel{\infty}{\infty}$ & & gi & $\stackrel{\mathfrak{v}}{\mathfrak{v}}$ & 1 & $\stackrel{0}{0}$ & $\bigoplus$ & ! & న & & $\overline{6}$ & & & & â & ai \\
\hline \multirow{5}{*}{ 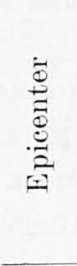 } & $E_{0}$ & $=$ & $B$ & $=$ & 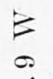 & 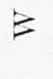 & 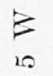 & $=$ & $=$ & 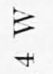 & $\geqslant$ & $\vec{\infty}$ & $\angle$ & 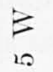 & $B$ & $=$ & 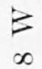 \\
\hline & $\bar{c}$ & $\dot{\infty}$ & $\stackrel{10}{\circ}$ & $\dot{\leftrightarrow}$ & $\dot{\infty}$ & $\infty$ & $\stackrel{1}{N}$ & $\dot{R}$ & ชี & $\dot{\mathbb{N}}$ & $\stackrel{R}{i}$ & $\dot{\Gamma}$ & $\stackrel{0}{1}$ & $\dot{i}$ & $\stackrel{10}{\mathrm{~N}}$ & $\stackrel{\dot{\sim}}{\stackrel{\sim}{N}}$ & $\dot{ \pm}$ \\
\hline & Z & z & Z & z & Z & z & 乙 & z & $z$ & TS & $w_{2}$ & $w_{2}$ & is & Un & 乙. & 乙 & $z$ \\
\hline & ๙ & 0 & & 0 & $\rightarrow$ & 10 & $\theta$. & 18 & & + & 28 & r. & & 20. & & 0. & 18 \\
\hline & $\infty_{10}^{\infty}$ & is & 10 & I- & $\stackrel{\oplus}{-}$ & I & 0 & $\infty$ & $\stackrel{\infty}{\simeq}$ & $\infty$ & ले & $\vec{m}$ & $\stackrel{10}{+}$ & $\stackrel{10}{7}$ & $\bar{F}$ & $\stackrel{9}{+}$ & $\exists$ \\
\hline \multirow{4}{*}{ 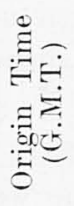 } & \multirow{4}{*}{ 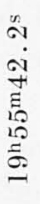 } & 10 & & 1- & 0 & & + & Q & & $\sigma$ & & I & & & & 0 & 10 \\
\hline & & iि & $\stackrel{\infty}{+}$ & 5 & $\ddot{\leftrightarrow}$ & $\infty$ & 10 & बे & คิ & $\overline{0}$ & 욱 & is & $\dddot{\varkappa}$ & $\exists$ & $\stackrel{\infty}{+}$ & $\stackrel{\leftrightarrow}{\mathrm{N}}$ & 10 \\
\hline & & $\dddot{\circledast}$ & 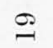 & م0 & ลิ & $\cong$ & 5 & 8 & $\stackrel{1}{0}$ & $\stackrel{f}{f}$ & 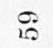 & $\Xi$ & $\vec{\sigma}$ & 10 & ニ & $\infty$ & $\stackrel{\sim}{\sim}$ \\
\hline & & to & $\stackrel{0}{=}$ & $\ddot{8}$ & $\stackrel{\Im}{a}$ & $\S$ & $\stackrel{\theta}{-}$ & $\bar{c}$ & $\exists$ & $\infty$ & $\stackrel{\oplus}{-}$ & \pm & $\stackrel{\infty}{\infty}$ & 20 & 0 & 5 & 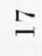 \\
\hline \multirow{3}{*}{ 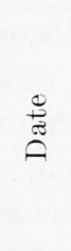 } & $\begin{array}{l}\mathscr{0} \\
\stackrel{0}{0}\end{array}$ & $\stackrel{0}{0}$ & $\begin{array}{l}8 \\
0 \\
0\end{array}$ & $\bar{\sigma}$ & $\begin{array}{l}\sigma \\
\sigma \\
\sigma\end{array}$ & $\begin{array}{l}8 \\
0 \\
0\end{array}$ & $\stackrel{8}{0}$ & $\begin{array}{l}\mathcal{O} \\
\stackrel{0}{0} \\
\sigma\end{array}$ & $\stackrel{8}{0}$ & $\stackrel{0}{0}$ & $\stackrel{0}{0}$ & $\stackrel{0}{0}$ & $\begin{array}{l}0 \\
\dot{0}\end{array}$ & $\stackrel{8}{\mathscr{0}}$ & $\begin{array}{l}0 \\
\mathscr{0} \\
0\end{array}$ & $\begin{array}{l}0 \\
\dot{0} \\
0\end{array}$ & $\stackrel{0}{0}$ \\
\hline & 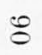 & గ్ & $\stackrel{\infty}{\circ}$ & क्र & $\stackrel{9}{-1}$ & $\stackrel{\infty}{\sim}$ & $\stackrel{\Omega}{\sim}$ & $\stackrel{\infty}{0}$ & $\vec{\infty}$ & $\overline{0}$ & คิ & $\stackrel{m}{-}$ & ลิ & $\stackrel{8}{\circ}$ & $\stackrel{8}{0}$ & $\ddot{0}$ & $=$ \\
\hline & $\stackrel{0}{0}$ & $\dot{\vec{z}}$ & $\stackrel{\varrho}{\Xi}$ & $\underset{Z}{\dot{Z}}$ & $\dot{\mathrm{a}}$ & $\stackrel{\dot{\Xi}}{\Xi}$ & $\underset{\mathscr{\sigma}}{\stackrel{0}{0}}$ & $\stackrel{\Xi}{\Xi}$ & $\frac{\vec{E}}{3}$ & $\frac{\dot{0}}{\not 1}$ & $\stackrel{\varrho}{\Xi}$ & $\stackrel{00}{3}$ & $\frac{\pi}{2}$ & $\stackrel{\Xi}{\Xi}$ & $\stackrel{\varrho}{\Xi}$ & $\stackrel{\dot{\theta 0}}{\Xi}$ & $\stackrel{\mathscr{\Xi}}{\Xi}$ \\
\hline \multirow{11}{*}{ 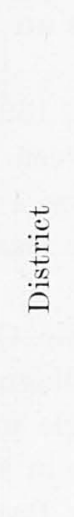 } & . & . & . & & . & . & . & & & . & . & . & . & . & . & . & . \\
\hline & . & $\cdot$ & $\cdot$ & . & $\cdot$ & $\cdot$ & . & $\approx$ & . & . & . & $\cdot$ & $\cdot$ & . & $\stackrel{\pi}{\exists}$ & . & . \\
\hline & • & • & 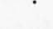 & • & $\cdot$ & 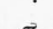 & • & $\vec{\tau}$ & 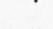 & $\cdot$ & & 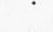 & 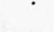 & 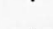 & $\overline{0}$ & $\overline{0}$ & r \\
\hline & . & . & . & . & . & క్ & $\ddot{e}$ &.$\Xi$ & . & . & . & . & . & . & కี & $\overline{\text { से }}$ & . \\
\hline & $\exists$ & $\Xi$ & $\exists$ & • & • & $\overrightarrow{\tilde{A}}$ & 5 & $\bar{\rho}$ & & $\cdot$ & & 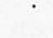 & $\cdot$ & $\cdot$ & $=$ & $\exists$ & 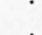 \\
\hline & $\stackrel{\mathscr{\Xi}}{0}$ & $\stackrel{巳}{0}$ & $\stackrel{\ominus}{0}$ & . & 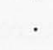 & 4 & $\tilde{\sigma}$ & & . & $\stackrel{\varrho}{\Xi}$ & . & $\stackrel{\stackrel{\varrho}{\Xi}}{\Xi}$ & 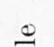 & $\stackrel{\varrho}{\Xi}$ & $\stackrel{\varrho}{\leftrightarrows}$ & $\stackrel{0}{=}$ & . \\
\hline & 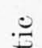 & $\stackrel{\bullet}{ت}$ & $\because$ & స్ & . & $\overrightarrow{d n}$ & 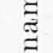 & 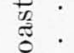 & $\stackrel{\Xi}{\Xi}$ & 4 & . & 4 & $\bar{\Xi}$ & + & $\overrightarrow{0}$ & $\frac{\overrightarrow{6}}{4}$ & $\cong$ \\
\hline & $\bar{E}$ & Е & छี & 8 & $\dot{0}$ & $\stackrel{8}{8}$ & $\overbrace{}^{3}$ & $=$. & $\stackrel{\vec{A}}{二}$ & + & . & 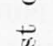 & tै & 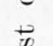 & 3 & 5 & త్ \\
\hline & 4 & \pm & 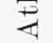 & 0 & ల్ల & $\stackrel{ \pm}{ \pm}$ & . & 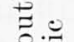 & $=$ & 范 & $\cdot$ & $\tilde{z}$ & $\vec{g}$ & శ్ & $\vec{S}$ & $+\infty$ & - \\
\hline & 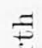 & 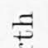 & 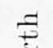 & $\stackrel{3}{\Xi}$ & $\overline{\widetilde{\pi}}$ & $\bar{D}$ & $\vec{\Xi}$ & $\begin{array}{l}5 \overline{0} \\
\approx \approx\end{array}$ & $\bar{z}$ & $=$ & $\subseteq$ & $=$ & $\stackrel{0}{0}$ & $\approx$ & 8 & 8 & 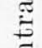 \\
\hline & $\dot{z}$ & z & $\dot{z}$ & 声 & $\bar{c}$ & $\stackrel{0}{0}$ & 8 & & $\stackrel{0}{\leftrightarrows}$ & $\ddot{z}$ & Еี & ż & 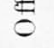 & $\ddot{z}$ & 0 & 5 & 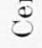 \\
\hline$\dot{0}$ & $\stackrel{\sim}{\mathscr{2}}$ & $\mathbb{R}$ & $\stackrel{5}{\circ}$ & $\ddot{\sim}$ & $\underset{\infty}{+}$ & \pm & $\stackrel{10}{9}$ & ig & $\dddot{m}$ & $\stackrel{\infty}{\dddot{2}}$ & $\stackrel{\vartheta}{0}$ & $=$ & $\stackrel{10}{-\infty}$ & $\stackrel{g}{\theta}$ & $\stackrel{\infty}{0}$ & $\stackrel{0}{=}$ & $=$ \\
\hline
\end{tabular}


Ridge. It is quite natural to assume the special feature to result from the special crustal condition beneath the Mid-Atlantic Ridge. This suggestion is ascertained by the Rayleigh wave dispersion from shock 107 , of which the path covers the northern part of the Mid-Atlantic Ridge. The dispersion data from this shock are shown in diagram $a$ ) of Fig. 5. In this diagram, data for other shocks along the Mid-Atlantic Ridge are also given. Considering the path, Rayleigh wave dispersion from shock 107 only is expected to belong to a special type. We denote this by $(h)$, which is also shown in diagram $b$ ) of Fig. 4 for comparison.

In the diagram $a$ ) of Fig. 5, the southern two shocks 107 and 26 only could supply us with Love wave dispersion data. The path from 26 contains the larger percentage of oceanic region and exhibits a more oceanic type (V) than the former (VI). The characteristic curve (V) corresponds to a theoretical curve B, calculated by Yamaguchi (personal communication; see also Yamaguchi and Kizawa 1961) for a crustal model as shown in the right hand of Fig. 5. Rayleigh wave dispersion from shock 26 is also more oceanic (4) than from 107.

Diagram $b$ ) in Fig. 5 shows the dispersion of Love waves from shocks 152 and 133 and Rayleigh waves along paths over the western part of the Atlantic Ocean. Love wave dispersion data agree well with an oceanic reference curve (IV) which also corresponds to a theoretical curve $\Lambda$ calculated by Press and Ewing (1955) for a crustal structure as shown in the right hand of Fig. 5. The dispersion of Rayleigh waves is most continental (4-5) along the path from 84 to Uppsala, which passes very near the eastern coast of North America, and most oceanic (3) along the paths from 152 and 133 to Uppsala, which pass near the deep sea region with a depth of more than $6 \mathrm{~km}$. All these results are quite reasonable.

From two pairs of Rayleigh wave dispersion data for $(81,132)$ and (133, 79), regional group velocities of Rayleigh waves between these epicenters have been calculated. The results are given in Fig. $4 a$ ) by filled and open circles respectively. They agree well with the classified curves (4) and (1) respectively.

Though they contain only a small part of North Atlantic Ocean, the dispersion data from 108, 110 and 11 are shown in the diagram $c$ ) of Fig. 5. In the same diagram, the dispersion data (triangle marks) obtained by Båth (1959) along a path, marked by a dotted line in Fig. 4, are added. His data belong to (VII) for Love and to (7) for Rayleigh wave dispersion respectively. 


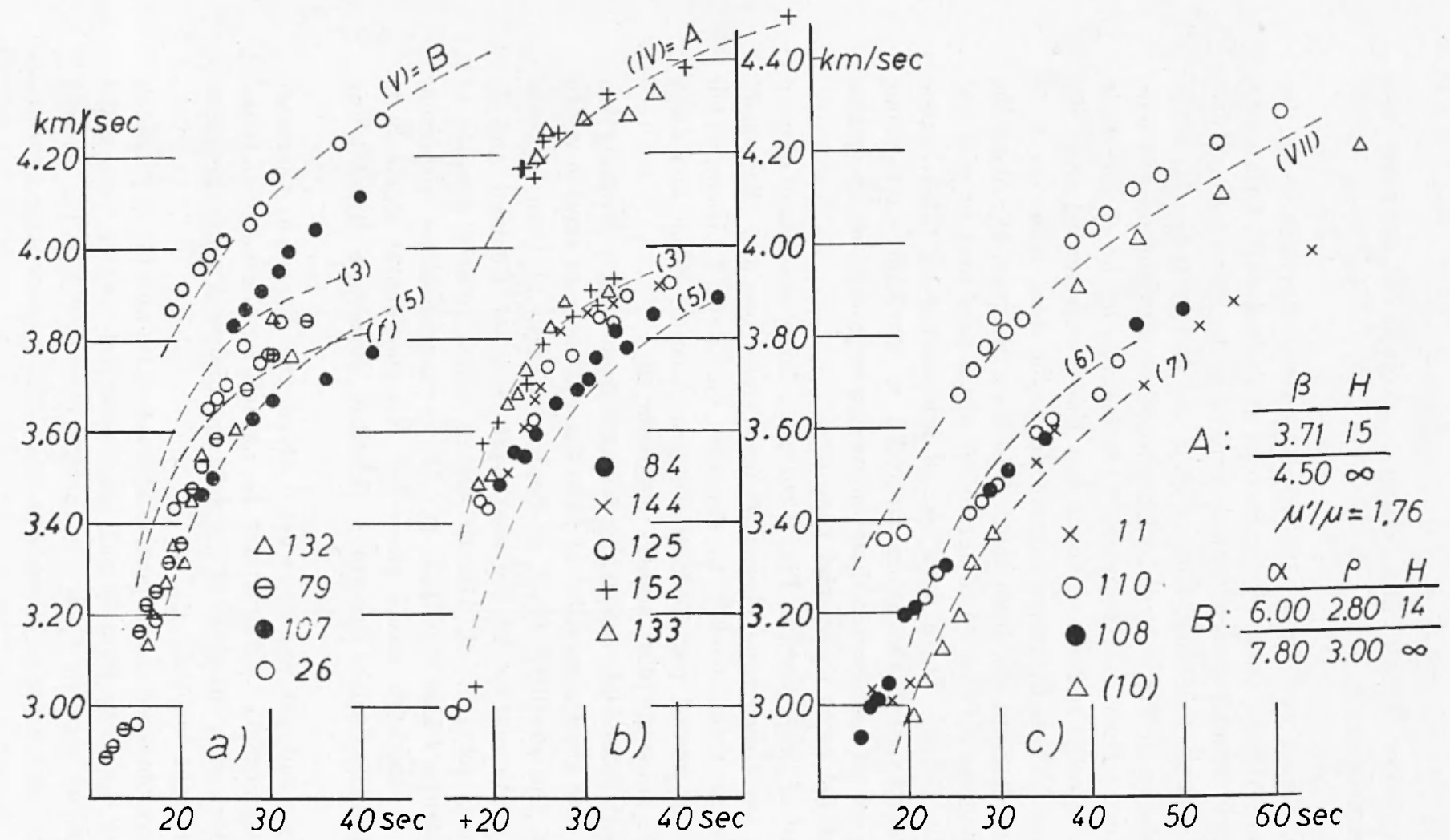

Pig. $5-$ a) Dispersion for shooks in the Mid-Atlantic Rilge. Rayleigh wave dispersion from shock 107 (filled circles) show a special type, for which the symbol $(h)$ is nsed.

b) Dispersion data for the Atlantic Ocean.

c) Dispersion data along paths throngh Canada and fireenland.

$\alpha$ and $\beta$ : velocities of $P$ and $s$ waves in $\mathrm{km} / \mathrm{sec}$ respectively.

II: thickness of the layer in $\mathrm{km}$.

o: density in $\mathrm{gm} / \mathrm{ec}$.

$\mu^{\prime} / \mu$ : ratio of rigidity between lower and upper medium. 
SoMe DIscussion ABOUT THE CRLSTAL CONDITION BENEATH TIIE ATLANTIC OCEAN.

Oliver, Ewing and Press $(1955 b)$ determined Rayleigh wave dispersion along $A$ tlantic paths by the records at Palisades (P), Ottawa (O) and Kew (K). Similar determinations were made by Berckhemer (1956) by the records at Palisades, Kew, Lisbon (L) and M'Bour (M). The paths are shown in Fig. 6 by solid lines together with the present ones (dashed lines). Their data are plotted in diagrams $a$ ), b), $c$ ) and $d$ ), in which the velocity scales are about ten times exaggerated over the original ones. These diagrams contain dispersion data from shock $7 b$ to Palisades (diagram a)), from shock 8 to Kew (diagram $b$ )), along the paths V (diagram $c)$ ) and VI (diagram $d$ )) which pass over or near the Mid-Atlantic Ridge. These data are all represented by filled circles. It is noteworthy that the group velocities of Rayleigh waves along these paths are all depressed in their long period range without exception, i. e. they all belong to the special type $(h)$.

As most of these paths in Fig. 6 contain a large percentage of deep sea region, their dispersion characters are typical oceanic. Especially Rayleigh waves from shock 8 to Palisades, Ottawa and Iisbon, which pass over the central part of northwestern Atlantic Basin and Cape Verde Basin, show the most oceanic character (0).

Any path from Chile shocks, for instance from 138, to Uppsala can be divided into three segments: 1) from the epicenter to $4000 \mathrm{~m}$ repth contour ofl the northern coast of South America, 2) from Uppsala to $4000 \mathrm{~m}$ depth contour off the southwest coast of England and 3) the remaining segment of Atlantic Ocean which mostly consists of the Mid-Atlantic Ridge (see Fig. 4). If we assume some dispersion characters of Rayleigh waves along the two continental segments 1) and 2), we can calculate the group velocities along the Mid-Atlantic Rirlge.

We have not yet any knowledge about the dispersion character along the segment 1). But it may be natural for the moment to assume the dispersion character ( $\left.8^{\prime}\right)$, which was observed along the Asian continental paths (see Part I).

We have observed the dispersion characters (4) and (5) of Rayleigh waves along the paths from 79 and 132 respectively, which occupy the same region as segment 2) in the present case (see Fig. 4). Taking into account that segment 2) contains much higher percentage of conti- 


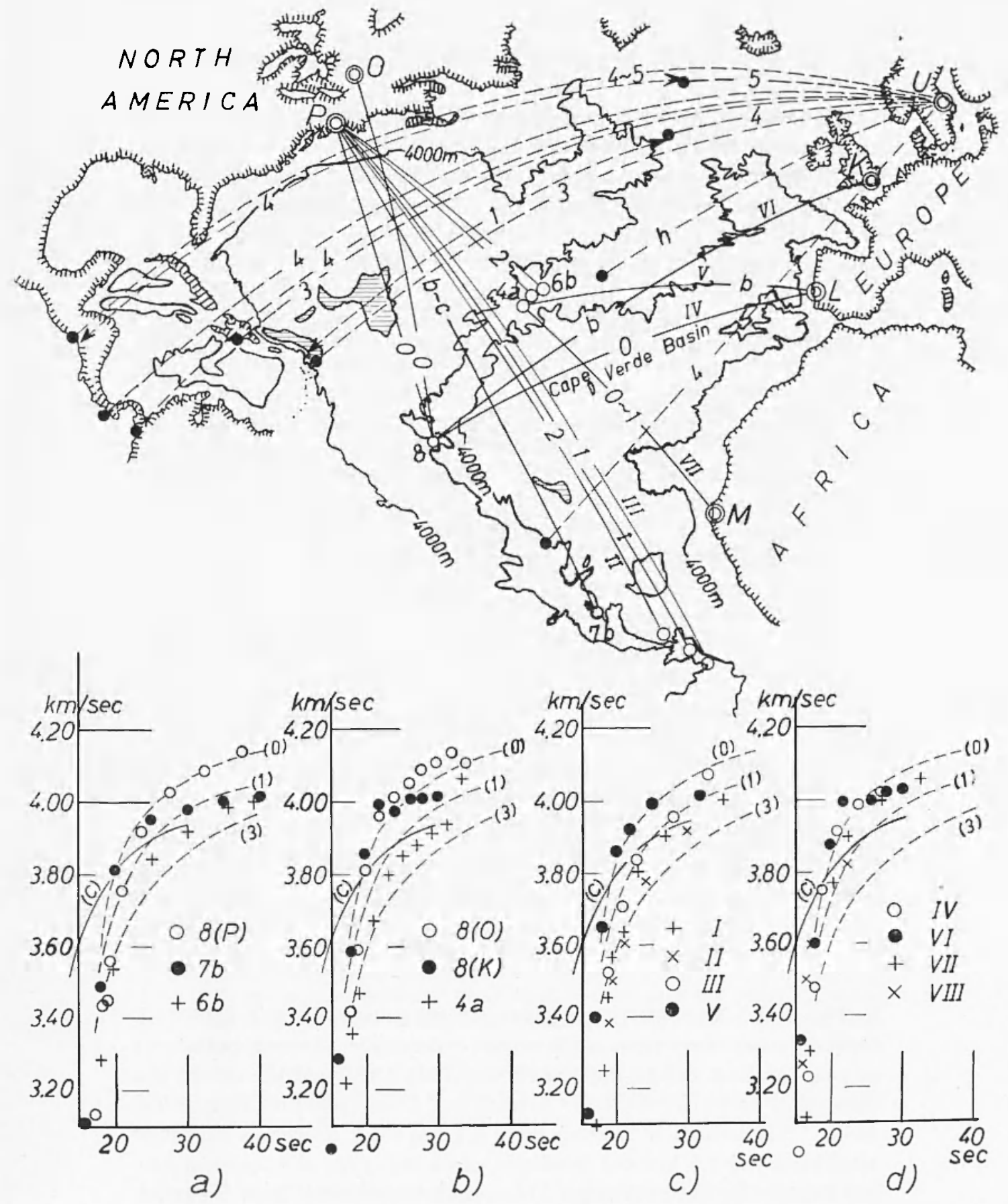

Fig. 6 - Travelling paths of Rayleigh waves over the Atlantic Ocean from other authors (solid lines) together with the present onos (dashed lines). Shock numbers or the namo of paths follow the original papers. Six observation stations are marked hy double open circles. Two regional dispersion curves, (1) and (4), of Rayleigh waves between two pairs of epicenters (133-79) and (84-132) respectively, shown in Fig. 4-a), are given. a), b) Rayleigl wave dispersion data by Oliver, Ewing and Press (1955b).

c), d) Rayleigh wave dispersion data by Berckhemer (1956). 
nental structure than these two, the dispersion character (6) may be assumed for the segment 2 ).

The path lengths along the three segments $D_{1}, D_{2}$ and $D_{3}$ are approximately $6000 \mathrm{~km}, 2000 \mathrm{~km}$ and $5700 \mathrm{~km}$ respectively. We can then calculate the travel times and group velocities of Rayleigh waves along the segment 3 ) (Table V). The results are plotted by filled circles

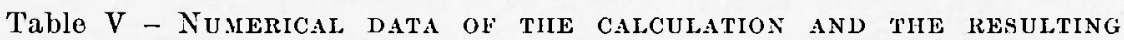
Group Velocities OF ratleigh WAVES along the CENTRAL MiDATIANTIC RIDGE.

$T=$ period; $\mathbf{V}$ - observed group velocity of Rayleigh waves along the total path; $r_{1}$ and $r_{2}=$ assumed group velocities of Rayleigh waves along the segmens 1) and 2), $D=$ total path length; $D_{1}, I_{2}$ and $D_{3}$ $=$ path lengths along the segments 1 ), 2) and 3 ) respectively; $r_{3}=$ calculated group velocity of Rayleigh waves along the segment 3 ).

\begin{tabular}{|c|c|c|c|c|c|c|c|c|}
\hline \multirow[b]{2}{*}{$T$} & \multicolumn{3}{|c|}{ Group velocity ( $\mathrm{km} / \mathrm{sec})$} & \multicolumn{4}{|c|}{ Travel time (sec) } & \multirow[b]{2}{*}{$V_{3}$} \\
\hline & $V$ & $T_{1}$ & $V_{2}$ & $D / \mathbf{V}$ & $D_{1} / V_{1}$ & $I_{2} / T_{2}$ & $D_{3} / l_{3}$ & \\
\hline 45 & 3.78 & 3.62 & 3.78 & 3620 & 1655 & 530 & 1435 & 3.97 \\
\hline 40 & 3.74 & 3.55 & 3.72 & 3660 & 1690 & 538 & 1432 & 3.98 \\
\hline 35 & 3.69 & 3.45 & 3.62 & 3710 & 1740 & 553 & $1+17$ & 4.02 \\
\hline 30 & 3.61 & 3.30 & $3.5 \mathrm{I}$ & 3800 & 1820 & 570 & 1410 & 4.04 \\
\hline 25 & 3.48 & 3.11 & 3.35 & 3940 & 1930 & 598 & 1412 & 4.03 \\
\hline 20 & 3.28 & 2.94 & 3.12 & +180 & 2040 & 641 & 1500 & 3.80 \\
\hline
\end{tabular}

in Fig. 7-a). Two curves are given for comparison in this figure. A dashed-dotted curve $(c)$ is a dispersion curve observed along paths over or near the East Pacific Rise (Santo and Băth 1962) and the dotted is a theoretical curve calculated by Kovach and Press (1961) for their model 1588. This consists of a water layer $4.1 \mathrm{~km}$ thick overlying a crust of total thickness $5.2 \mathrm{~km}$ and consisting of three layers; the upper mantle has fourteen layers, including a $33 \mathrm{~km}$ thick low-velocity layer beginning three $\mathrm{km}$ below the Mohorovicic discontinuity.

In Part I we found that Rayleigh wave dispersion from shock 21 (Sandwich Islands region, 56.10S, $27.3^{\circ} \mathrm{W}$, Sept. 08, 1961) also slowed 
a special type $(f)$. We can then make the same investigation assuming the dispersion character of Rayleigh waves along the continental part, from Uppsala to the $4000 \mathrm{~m}$ depth contour off southwestern coast of Africa (see the central map of Fig. 7). In this case, a characteristic
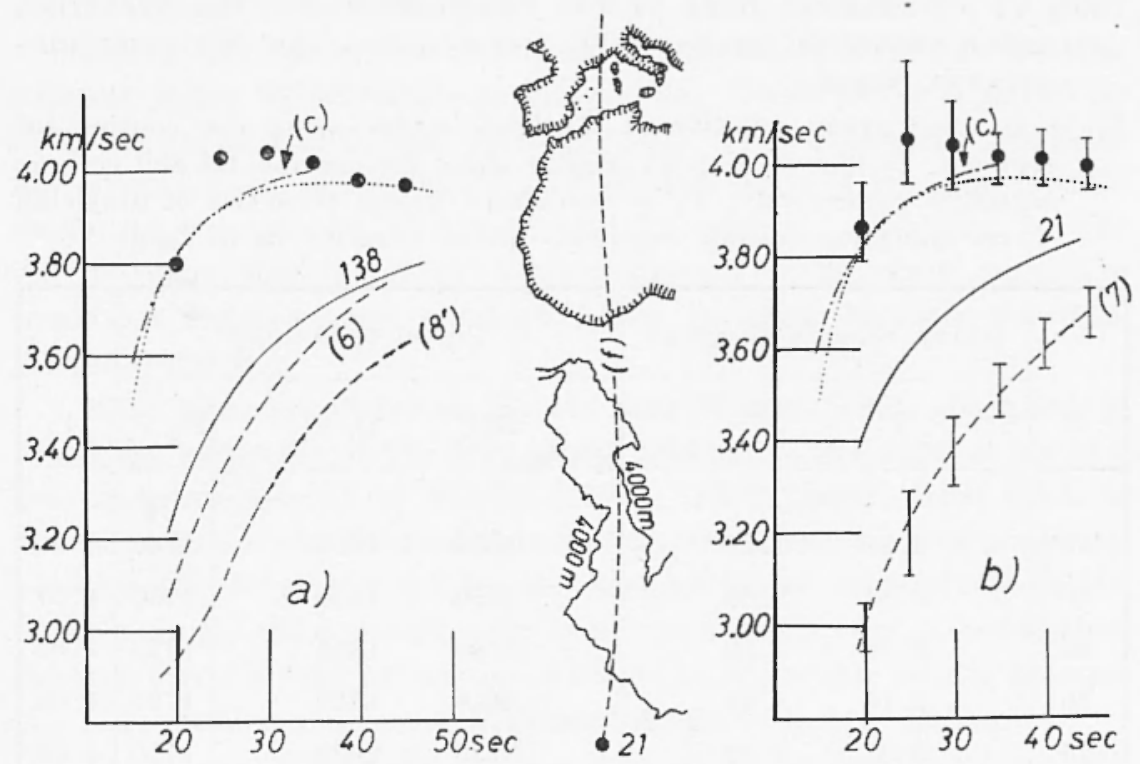

Fig. 7 - a) Filled circles: calculated group velocities of Rayleigh waves along a path over the central Mid-Atlantic Ridge.

Solid curve: observod dispersion of Rayleigh waves from 138.

Dashed curves: assumed dispersion of Ravleigh waves along the two continental paths.

Dotted curve: theoretical dispersion after Kovach and Press (1961) for the model 1588.

Dashed-dotted curve: Classified curve (c).

b) Similar to diagram a) but for shock 21 .

Upper and lower linits of vertical bars around the eurve (7) mean the group velocities of Rayleigh waves when they follow the characteristic curves of (6-7) and (8') respectively, and lower and upper linits around filled circles mean the corresponding result.

Niddle map: A part of the travelling path from 21 (dashed line). Iocation of Ridge is indicated by the depth contour of $4000 \mathrm{~m}$.

curve (7), slightly more oceanic than (8') was assumed for the continental segment, because the characteristic numbers (6) to (7) were found for other parts of Africa (Part I). The group velocities of Rayleigh waves as calculated for the oceanic segment containing the southern part of 
the Mid- $\Lambda$ tlantic Ridge are given in Table VI and Fig. $7-b$ ). It is interesting to note, that the results are nearly the same as in the previous case.

Table VI - Numerical data of the calculation and the resulting: GROUP VELOCITIES OF RAYLEIGII WAVES ALONG THE SOUTHERN MID. ATLANTIC RIDGE.

$Y_{1}=$ assumed group velocity of Rayleigh waves along the continental segment, $D_{1}$ and $D_{2}=$ path lengths along the continental and oceanic segments respectively, $\mathrm{V}_{2}=$ calculated group velocities of Rayleigh waves along the oceanic segment. Other notation as in Table V.

\begin{tabular}{|c|c|c|c|c|c|c|}
\hline \multirow[b]{2}{*}{$T$} & \multicolumn{2}{|c|}{ (iroup volocity $(\mathrm{km} / \mathrm{sec})$} & \multicolumn{3}{|c|}{ Travel time (sec) } & \multirow[b]{2}{*}{$r_{2}$} \\
\hline & $r$ & $r_{1}$ & $I) / V$ & $D_{1} / \Gamma_{1}$ & $n_{2} / \Gamma_{2}$ & \\
\hline 45 & 3.84 & 3.68 & 3500 & 1765 & 1735 & 4.00 \\
\hline 40 & 3.81 & 3.60 & 3530 & 1800 & 1730 & 4.01 \\
\hline 35 & 3.76 & 3.50 & 3580 & 1855 & 1725 & 4.02 \\
\hline 30 & 3.70 & 3.38 & 3640 & 1920 & 1720 & 4.04 \\
\hline 25 & 3.61 & 3.22 & 3730 & 2020 & 1710 & 4.06 \\
\hline 20 & 3.40 & 3.00 & 3960 & 2163 & 1797 & 3.87 \\
\hline
\end{tabular}

It is important to know to what extent the calculated dispersion along the purely oceanic segments is influenced by the assumed dispersion along other segments. For this purpose, the group velocities of Rayleigh waves along the continental segment in the second ase were changed in the range shown by vertical bars around the curve (7). In Fig. $7-b$ ) upper and lower limits of vertical bars around the curve (7) mean the group velocities of Rayleigh waves when they follow the characteristic curves of $(6-7)$ and $\left(8^{\prime}\right)$ respectively, and lower and upper limits around filled circles mean the corresponding calculated results. The calculated group velocities of Rayleigh waves lie very well on the theoretical curve, when we assume (6-7) curve along the continental segment. As the continental segment in this case contains both the Meditermanean Sea and a water-covered region south of Africa, velocities lower than curve (7) are unlikely for this segment. This means that oceanic velocities higher than the dots are unlikely. In any case, the 
special dispersion character found for Rayleigh waves, i. e. the depressed group velocities in the longer period range, is predominant both along the central and the southern Mid-Atlantic Ridge. Moreover, if the assumptions made for other segments are correct, they are both similar to that along the Eastern Pacific Rise.

Ewing and Ewing (1959) studied the crustal structure on the MidAtlantic Ridge by refraction measurements. Their profile is shown by a double arc in Fig. 6, near epicenter 107. They observed remarkable low compressional relocities $(7.2-7.3 \mathrm{~km} / \mathrm{sec})$ under a layer of basaltic rock with the velocity of $5.15 \mathrm{~km} / \mathrm{sec}$ in average. Referring to the gravity anomalies found by Vening Meinesz (1948), they suggest a " root", a massive layer as thick as $30 \mathrm{~km}$ just beneath the MidAtlantic Ridge.

IIore recently, Talwani, Heezen and Worzel (1961) discussed in detail the structure of the Mid-Atlantic Ridge in the light of the new gravity measurements by Worzel (1959). They present three kinds of crustal models under the assumption of the usual values of compressional velocity and density of $8.2 \mathrm{~km} / \mathrm{sec}$ and $3.4 \mathrm{gm} / \mathrm{cc}$ respectively in the upper mantle. The model considered most likely, has a bell-shaped inserted layer of $7.00 \mathrm{~km} / \mathrm{sec}$ and $3.05 \mathrm{gm} / \mathrm{cc}$ above the mantle beneath the Ridge with a maximum thickness of approximately $15 \mathrm{~km}$.

Tryggrason (1961) also found a layer of $7.4 \mathrm{~km} / \mathrm{sec}$ from his study of travel times of body waves from four earthquales in the central part of the sea area between Greenland and Norway. This 7.4-layer was found by the same author (Tryggrason 1962) also from dispersion of surface waves along the northern IIid-Atlantic Ridge including Iceland. He supposed that this 7.4-layer might belong to the mantle, although its wave velocity is significantly lower than usually found in the upper mantle.

From the refraction data by Raitt and Shor, Menard (1960) suggests that the mantle with a low velocity might ascend beneath the Eastern Pacific Rise.

The present results of Rayleigh wave dispersion along paths over the Mid-Atlantic Ridge agree with these models at least in one respect, i. e. they indicate a rather shallow discontinuity beneath the Ridge. Furthermore, the calculated group velocities of Rayleigh waves along the Mid-Atlantic Ridge, given in Fig. 7, require a low-velocity layer beneath the Ridge. 


\section{Concutsions.}

Dispersion of Lore and Rayleigh waves of the first mode were investigated along various paths in the Aretic and Atlantic Ocean by means of records at Eppsala. The Aretic Ocean is divided into four regions (1), (3), (5) and (7) with the Rayleigh wave dispersion chanacters (1), (3), (5) and (7) respeectively (Fig. 3). The boundaries of the four regions coincide approximately with the depth contours of $4000 \mathrm{~m}$, $2000 \mathrm{~m}$ and $1000 \mathrm{~m}$ respectively, expect in some areas of the easterm part of the ocean. The crustal structure of the Aretic Ocean thus exhibits the same relation to the depth of the sea, as found earlier for the Pacific Ocean, east of the Andesite line. It is also suggested that the reggion with more oceanice cerustal structure than the region (3) may prevent the propagation of $\mathrm{L} g \mathrm{~g}$ wares.

For the Atlantic Ocean, we have reached the following conchusions:

1) Along the whole of the Mir-Atlintic Ridge, Rayleigh waves show a special dispersion chatacter', which agrees well with the existence of a "root" under the Mid-Atlantic Ridge, which Ewing and Ewing (1959) suggest by their refuaction measurements.

-2) The crustal structure in the southern part of northwestern Atlantice Basin and Cape Verde Basin are as oceanic as in the central part of the Pacific Ocean.

3) The crustal structure in the northern part of Atlantic Ocean corresponds in arerage to dispersion character (5).

\section{ACKNOWJEI)(HENTS.}

The research reported in this paper has been earried ont at the Seismologieal Institute, Uppsala, and was made possible through the support and sponsorship of the U.S. Department of Army, through its European Research Office (Contract No. DA-91-591-EUC-1637, Mod. 1). The writer would like to express his sineere thanks to the institutions.

The writer"s great thanks are also due to Dr. Markus Băth, who gave him valuable opportunity to continue his work at Uppsala, and helped and encouraged him during the investigations.

Part of the present research is based upon records written by PressEwing seismographs at Uppsala, which are on loan from Lamont Geological Observatory, Palisades, N.Y.

Seismological Institule, Lppsala, sweden September, 1962 


\section{$S U M M R Y$}

Group velocity dispersion of surface waves of the first mode along various oceanic paths is investigated by means of records at Upusala. The Arctic Ocean can be divided into four regions according to the character of Rayleigh nace dispersion. Rayleigh waces which pass over or near the Mid-Atlantic Rirlye show a special dispersion character, the same as found along paths over or near the Eastern Pacific Rise.

\section{RIASSUNTO}

Presso l'Eniversità di Uppsala, ì stata studiata, a mezo di sismogrammi, la dispersione del primo modo della velocita di gruppo delle onde superficiali, lungo tragitti oceanici.

Per il tipo di dispersione delle onde di Rayleigh, POceano Artico può essere diviso in quattro zone.

Le onde di Rayleigh che attraversano o sfiorano la dorsale Media-Atlantica, hanno un particolare tipo di dispersione, lo stesso che istato trovato per $i$ tragitti che interessano loceano Pacifico Orientale.

\section{REFERENC:ES}

BенскIEnER H., Rayleigh-Wave Dispersion and Crustal Structure in the East Allantic Ocean Basin. "Bull. Seis, Soc. Amer. ", 46, 83-86, (1956).

BAтt X., Seismic Surjace-Wave Dispersion: A World-Wide Survey. "Geofisira Pura e Applicata", 43, $131-147$, (1959).

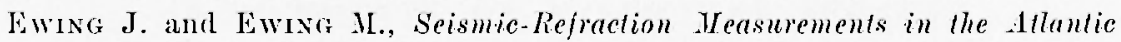
Ocean. Basin, in the Mediterranean Sea, in the Mid-stlantic Ridge, and in the Norregian Sea. "Bull. Geol. Soc. Amer." 70. 291-318. (1959).

HeEzex B. ( $\therefore$ and Ewing M., The Mid-oceanic Ridge and its Ertension through the Arctic Basin. "Geology of the Arctic", 622-642, (1961).

HoPE E. R., Geolectonics of the Aretic Ocean and the Great Aretic ILagnetic Anomaly. "Jour. of Geopliys. Res.", 64, 407-427, (1959).

Kovacir R. I. and Priss F., Rayleigh Wave Dispersion and Crustal Structure in the Eastern Pacific anl Indian Ocean. "Geophysical .Tour. Roy. Astron. Soc." 4, 202-216, (1961).

Menard H. W., The East Pacific Rise. "Science", 132, 1737-1746, (1960). Ononisa S. F., On the Problem of the Earth's Crust in the Aretic (in Russian). "Izv. Akarl. nauk SSSR". Ser. geof., 6, 818.821, (1961). 
Oldver J. E. - Ewisg .1. and Press F., Grustal structure of the Aretic Regions from the Lg phase. "Bull. Geol. Soc. Amer.", 66, 1063-1074, (1955 a).

-, Crustal Structure and Surface-Wave Dispersion, Part IV: Allantic and Pacific Ocean Basins. "Bull. Geol. Soc. Amer.", 66, 913-946, (1955 b).

P’kess F. and Ewag M., Earthqule Surface Waves and Crastal structure. "Geol. soc. Amer.", special Paper 62, 51-60, (1955).

SAxto 'T. A., Division of the South-IVestern I'acific thea into Several Regions in each of which Rayleigh Waves have the Same Dispersion Characters. "Bull. Earthq. Res. Inst.", 39, 603-630, (1961).

--, Dispersion of Surface Waves along Various Palls to Tppsala, Sueden. Part. 1, Continental Paths. "Annali di Geofisica", (in press, 1962).

SAxTO T. A. and BATn M., Crustal Structure of Pacific Ocean Area from Dispersion of Rayleigh Waves. "Bull. Seis. Soc. Amer.", (in press, 1962).

TAlwayi M. - IIEezen B. C. and Worzer J. I., Gravily Anomalies, Physiography, and Crustal structure of the Mid-Atlantic Ridge. "Pub. Bur. 'en. Int. Sćism.", series A. Trav. Sci., 22, 81-111, (1961).

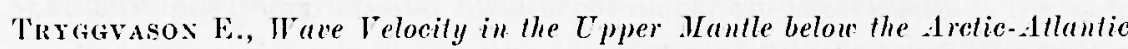
Ocean and Northwest Europe." Annali di Geofisica", 14, 379-392, (1961).

-, Crustal Structure of the Iceland Region from Dispersion of Surface Waves. "Bull. Seis. Soc. Amer.", 52, 359-388, (1962).

Vexisi Ilensesz F. A., Gratity Expeditions at Sett, 1923-1938. "Delftsche Vitgevers Maatschappy ", 4, 233, (1948).

Worzer. J. I.., Continuous Gravity Measurements on a Surface Ship with the Graf sea Gravimeter. "Jour. Geophys. Res.", 64. 1299-1315, (1959).

Yavaguch R. and KIzaWa T., Surface IVaves and Layered Struchures, Part. 2, Theoretical dispersion carves for suboceanic surface waves. "Bull. Earth. quake Res. Inst.", 39, 669-809, (1961). 